\title{
Costs of Wood Pellet Production in Iran
}

\author{
Vahid Nabavi, Majid Azizi*, Asghar Tarmian \\ Department of Wood \& Paper Sciences and Industries, Faculty of Natural Resources, College of Agriculture and Natural Resources, \\ University of Tehran, Tehran, Iran \\ Email: *mazizi@ut.ac.ir
}

How to cite this paper: Nabavi, V., Azizi, M. and Tarmian, A. (2016) Costs of Wood Pellet Production in Iran. iBusiness, 8, 3747.

http://dx.doi.org/10.4236/ib.2016.83005

Received: July 7, 2016

Accepted: August 22, 2016

Published: August 25, 2016

Copyright $\odot 2016$ by authors and ScientificResearch Publishing Inc. This work is licensed under the CreativeCommons Attribution International

License (CC BY 4.0).

http://creativecommons.org/licenses/by/4.0/

\begin{abstract}
Climate changes and increased Earth's temperature form a phenomenon that affects all humans and countries. Consequently, even countries with plenty of fuel energy resources have realized the importance of this issue. Wood pellet is among the most commonly used bio fuels and is spreading quickly all over the globe. In this research, the feasibility of wood pellet production in Iran was assessed by studying a production project and economically analyzing it. Based on the results, all of the economic indicates are reflective of economic utility of wood pellet production in Iran. For instance, the IRR index of the project was $64.54 \%$, and the final price of the product was 118.89 EUR per ton. Analysis of production costs indicated that raw materials had the highest share of the final price followed by fixed investment costs and energy costs.
\end{abstract}

\section{Keywords}

Wood Pellet, Biomass, Production Costs, NPV, IRR

\section{Introduction}

In recent years biomass has become the most important renewable source for heat generation [1]. The pelletizing of biomass involves the mass and energy densification of materials that possess low bulk densities such as sawdust, straw, and other herbaceous biomass. This process reduces transportation costs, and provides better handling and feeding of biomass with less dust formation [2] [3]. Since the raw materials suitable for production of wood pellet are wood residues and tailings of sawmills and wood processing plants, and availability potential of these materials has highly importance to feasibility studies and economic assessments of wood pellet production, Iran has considerable biomass resources estimated at 25 million tons per annual that can be utilized as source of raw materials for producing renewable energy, including small scale heat and power production using a variety of waste streams, dedicated energy crops and for- 
est residues [4].

According to the statistics by Ministry of Agriculture Jihad, 2.6 million hectares of the country is covered with dense forests, which make up $8.83 \%$ of Iran's area. In 2014, approximately $193,795 \mathrm{~m}^{3}$ of Iran's total production of wood products were firewood [5]. Although Iran is one of the biggest producers and consumers of fossil fuels in the world, it has enforced incentive policies and has taken measures for using renewable energies due to the destructive effects of fossil fuels and international constraints in Iran, and the national energy policy promotes renewable energy to address the key issues on energy security, the reduction of energy imports and reduction of Green House gas emissions [4]. The need for transition to sustainable energy resources has been recognized in Iran and Renewable Energy Organization of Iran has established various research programs for development of bio energy (green energy) production from biomass [6]. Many studies have also been carried out in this regard by the Renewable Energy Organization of Iran. According to 2014 world statistics, greenhouse gas emission in Iran was 616 million tons, which placed Iran tenth among producers of greenhouse gases. In this regard, in the Paris Climate Change Conference Iran committed to reduce four percent of its greenhouse gas emissions by 2030 and to increase the decrease to $12 \%$ with elimination of internal economic sanctions and financial-technological aids. The world's production of wood pellet reached 26 million tons in 2014, which was almost produced exclusively by Europe and North America. Projections assume continued increase of demand and indicate a potential global demand of 130 170 million ton per year in 2020 [7]. Asia's share of the world's production is 1.4 million tons. Existing data suggests that currently a wood pellet production company is operating in the north of Iran with a capacity of 60,000 ton/year. Considering economic sanctions on Iran and the increased economic collaboration between Iran and other countries, production of renewable energies such as wood pellet is logical in view of export goals and domestic consumption. Iran can play a significant role in supply of wood pellet as a renewable form of fuel by utilizing its suitable biomass resources. A model for technical and economic analysis of wood pellet production costs in the United States indicates that production of wood pellet can be cost-effective for American investors, and it is highly sensitive to biomass and workforce prices [8].

In another study a comparison was made between costs of production of wood pellet in Austria and Sweden, and advantages of each area were described. The direct comparison of typical pellet production costs in Austria and Sweden showed that the production costs were mainly influenced by the raw material costs and also showed that the Swedish pellet production costs should be considerably lower because of larger plant capacity (economy-of-scale) and an efficient recovering system from the dryers usually applied in Sweden [9]. A study carried out an analysis on costs of wood pellet production in five countries, namely Finland, Germany, Norway, Sweden, and United States. The study was carried out using two high- and low-capacity production models and showed that the pellet producers in the US had lower feedstock costs than producers in the analyzed European countries [10], the development of wood pellets production and consumption differed greatly between countries, and it was of high interest for 
forestry, forest industries and wood pellets producers to improve knowledge about the causes for the differences and their development [11].

The research objective was to conduct an economic assessment and feasibility study of wood pellet production in Iran based on Iran's economic indices, calculations of IRR (Internal Rate of Return) and NPV (Net Present Value) indices, and sensitivity analyses using principle variables for a case study.

\section{Methodology}

United Nations Industrial Development Organization (UNIDO) has proposed a methodology for guiding investors toward successful and interesting investment projects, especially in developing countries which are receiving a large load of investment projects. It could be stated that this methodology is currently the most applicable of its kind. This procedure manifests in COMFAR software and is available to the international society. Economic analysis of this project was carried out in COMFAR III. To start a pellet production plant it is essential to calculate the pellet production costs in advance in order to consider and investigate specific framework conditions of the producer for an economic operation. Technical information and parameters for make a framework are at Table 1 .

Inquiries about the overall production line price were made from a credible European company and results were compared to the information from similar research. The production process is depicted in Figure 1.

Due to density of forests and related industries such as sawmills, wood processing plants, and wood conversion plants, the production line will be established next to forests in the north of Iran. Initial investment costs such as costs of land, building, water, electricity, gas, and human force were determined by making inquiries from credible state centers, industrial developments, and appropriate administrations.

Table 1. Studied wood pellet production line technical parameter.

\begin{tabular}{ccc}
\hline \multicolumn{2}{c}{ Technical parameter for wood pellet plant } & \\
\hline Annual pellet production & 120,000 & Ton/annual \\
Annual production hours & 8000 & Hours \\
Cost of production line & $7,855,113$ & Euro \\
Service life of pellet production facilities & 20 & Years \\
Storage capacity & 0.4 & $\%$ \\
Drying type & Rotary drum & M3/ton \\
Natural gas consumption & 102 & Gwatt \\
Required electricity power & 1.5 & \\
Working and personnel & & Days \\
Shifts per day & 3 & Person \\
Working days per week & 7 & 16 \\
Personnel numbers & &
\end{tabular}


The ex-factory prices of suitable raw materials obtained from wood residues and tailings of sawmills and wood conversion industries were used. Cost price varies by season, which is assumed to be, 80 Euro/ton on average.

The price of the product, which is wood pellet, for domestic consumption was assumed to be equal to the ex-factory price based on the price of local producers. To carry out the project's economic analyses it is necessary to estimate all related costs, which include the following prices: land, building, installations, machinery, raw materials, energy, pre-go-live costs and unpredicted expenses Table 2.

\subsection{Land and Building}

Extensive investigations into the existing research resources were carried out to select the

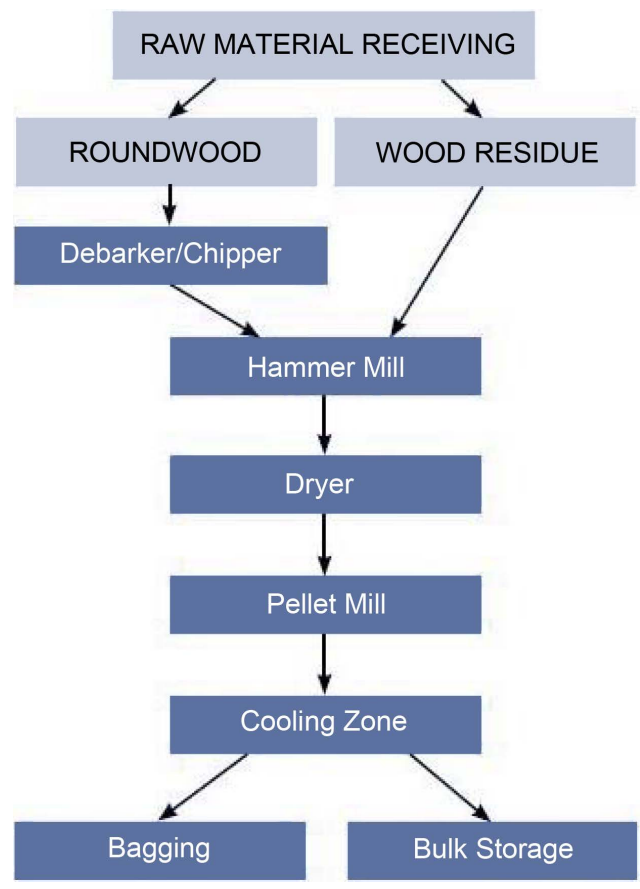

Figure 1. Wood pellet production diagram.

Table 2. Capital expenditures for 120,000 metric ton/year plant.

\begin{tabular}{ccc}
\hline Item & Required & Total cost (Euro) \\
Land & 1 & $7,855,113$ \\
Production line and equipment & 10,000 square meter & 174,422 \\
Land preparation & 1 & 193,003 \\
Building \& office space & 1 & 917,522 \\
Forklift & 3 & 143,982 \\
Industrial equipment & & 658,456 \\
Pre-Go-Live and Unexpected Expenses (5\%) & & 540,812 \\
Total & & $10,483,310$ \\
\hline
\end{tabular}


location for construction of the production plant. Northern provinces of Iran are the best for establishment of a large-scale wood pellet production plant due to their numerous wood resources and multiplicity of wood conversion and processing industries.

Considering provision of industrial services to factories and plants in industrial developments, land prices and costs of building operations were inquired from Industrial Developments and Contractors Company of North of Tehran.

\subsection{Production Line Machinery}

Inquiries were made with a European company about the price of a production line with a capacity of 120,000 tons/year. The prices include costs of machinery, financial expenditures, and installation costs.

It should be mentioned that the quoted price (7,800,000 Euro) seemed competitive when compared to prices published in other scientific references.

\subsection{Raw Materials}

One characteristic of wood pellet is the lack of diversity in composition of its raw materials. In fact, the raw material for all types of wood pellets (such as industrial grids and domestic products) is wood. Dry sawdust has historically been the main raw material for wood pellets production due to low prices, a relatively homogenous composition and, the most important of all, no need for thermal drying of feedstock [12]. Hence, the project is highly important economically, technically, and qualitatively.

The raw material available in the study area is mostly composed of wood residues and tailings of sawmills. However, wastes produced by woodcraft workshops and biomass produced by pruning also constitute the raw materials. The future production of wood pellets will mandatorily evolve to the use of wet raw materials and increment of production capacity, benefiting from the competitive advantages related to economies of scale [13].

Raw material prices are influenced by the following factors.

- Season: In some seasons of the year, the amount of available raw materials declines due to prohibition of harvest from forests and the decreased operation of wood processing units. This decrease subsequently results in a rise in prices.

- Moisture levels: Since the excess moisture in wood materials should be removed during wood pellet production, and since this process requires energy and budget, the moisture content of wood biomass is influenced by the moisture contents of raw materials.

- Distance from plant site: Another factor influencing the final price of raw materials used as the plant input is the cost of transportation of raw materials from the source to the plant site, which should be taken into account due to the need for fuel.

- Dimension and quality of wood pieces: Bulkiness of raw materials or effective raw material per unit volume, which is known as bulk density, is a measure of calculation of transportation costs. As bulk density decreases, transportation costs reduce. In addition, quality of the wood material will be more desirable due to the lower 
bark content.

- Cost price for rivals: A percentage of the wood biomass suiting wood pellet production is usable in other industries such as wood-based panels and coal production industries [14]. Hence, the cost price of wood material is influenced by rival industries, while competitiveness of the wood biomass market influences the end prices.

In this research, after field investigations and inquiries about cost prices from sellers of wood wastes and similar companies, an average price of 80 Euro/ton of raw material (wood) was used in economic analyses.

However, in practice, any specific price can be determined for any type of raw material depending on quality and other factors.

\subsection{Salaries and Wages}

Salaries and wages depend on many variables such as the number of working shifts and working weekdays as well as consumer market's conditions. In view of the information obtained from the manufacturer and technical predictions, a total of 16 human resources are required for this production line: 6 employees will work in the administrative and marketing divisions, and 10 will work as production line personnel 3 shifts per day and 7 days per week. Low-cost human force is one of the advantages of investment in Iran. Based on the latest report by Iran's Ministry of Labor, the minimum wage of workers for 44 hours a week is 60.91 euro. This figure is very insignificant as compared to European countries (e.g. 959 EUR in Austria and 690 EUR in Sweden [10]).

\subsection{Cost of Energy}

Electricity: According to the information provided by the production line manufacturer, an electricity post with a capacity of $1.5 \mathrm{MW}$ is required for going live. This power is mainly used for pellet compressing electromotors.

According to the tariff declared by Iran's Ministry of Energy, the kilowatt per hour price of electricity varies during the day depending on the low-, moderate, and highload hours. Since wood pellet is planned to be produced 24 hours a day, the average price of energy is assumed to be 0.037 euro per kilowatt/hour in calculations.

Natural gas: because of raw material dryer unit that consume natural gas, the second important energy carrier in the wood pellet production process is natural gas. Iran is the second highest producers of natural gas in the world, and the price of this product is low for domestic consumers. The dryer unit consumes a great deal of energy to reduce the moisture of raw materials to the desired level. A cylindrical dryer is proposed in the preliminary project plan. This dryer requires $103 \mathrm{~m}^{3}$ of natural gas to dehydrate one ton of wood raw material with a moisture content of $50 \%-55 \%$ based on its fresh weight.

\subsection{Overhead and Depreciation Costs}

Utilization of overhead systems and related operations can considerably influence the product final price. In this research, based on principles of feasibility studies of eco- 
nomic projects a percentage of the product value is allocated to overhead costs. These percentages are $5,5 \%$ and $20 \%$ for buildings, machinery/installation, and vehicles/furniture/office equipment, respectively.

Moreover, all of the costs incurred during the project construction phase should be amortized as production costs in the course of production based on requirements determined by the government. These prices affect the product final price, scrap price, and accrued taxes. The basis for determining the method and rates of calculation of assets depreciation is dictated each year in the "Direct Tax Code" by the legislator. The double declining balance method was employed in this research.

\subsection{Pre-Go-Live and Unexpected Expenses}

These expenses include costs of professional assistance, technical consulting, travels and personnel training and make up $5 \%$ of the fixed capital.

\section{Results}

The calculated final price of each ton of the end product (i.e. wood pellet) is 118.89 EUR. All of the operational costs constituting this price are divided into 5 categories Table 3 and the share of each category is shown in Figure 2.

According to this information, the largest share of the final price belongs to raw materials. Almost $82 \%$ of the product final price is incurred by this component. Therefore,

Table 3. Wood pellet operational costs for one year based on 120,000 ton/annum capacity.

\begin{tabular}{cc}
\hline Costs categories & Value/euro \\
\hline Raw material & $11,755,276$ \\
Salaries \& wages & 82,524 \\
Energy & 879,419 \\
Overhead and Depreciation Costs & $1,122,508$ \\
Other & 427,464 \\
\hline
\end{tabular}

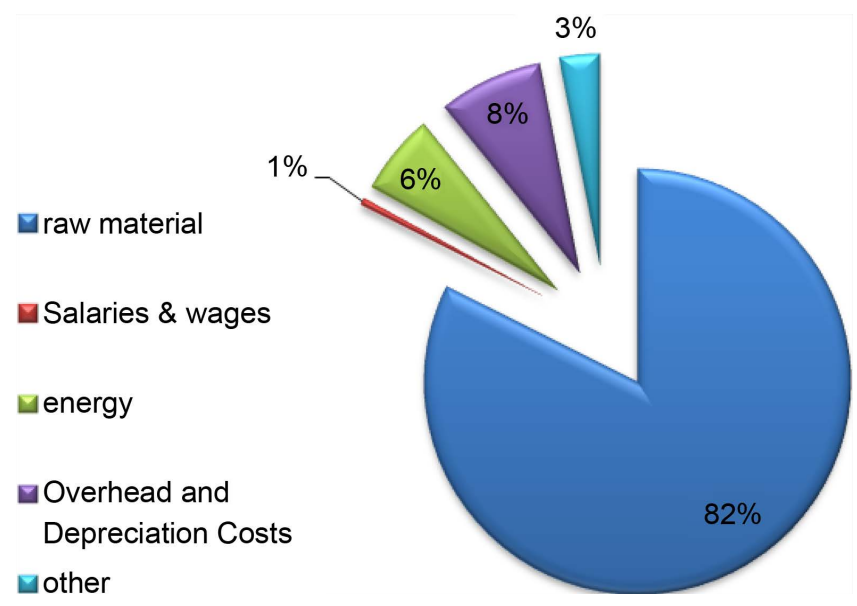

Figure 2. Breakdown of pellet operational costs. 
planning on preparation of high-quality and low-price raw materials will significantly contribute to the project profitability.

Another portion of the expenses forming the product final price is induced by the project's fixed investment costs, which include overhead, depreciation, and insurance costs. These costs make up $8 \%$ of the product final price, which is 8.35 EUR per ton of wood pellet.

Although the price of energy in Iran is much lower than many other countries, consumption of energy in this project is important since the main goal of this project is to produce a product to be used as an energy carrier. This is especially important when the energy is supplied by fossil fuel, which contradicts applications of wood pellet from the environmental point of view. Hence, equipment with high energy efficiency should be used to the possible extent. Based on the existing technical information on the equipment, natural gas is assumed for the dryer, while electricity is assumed for transportation and pressing equipment. Six percent of the final price is explained by consumption of energy (i.e. natural gas and electricity), which is calculated to be 7.32 EUR. Other factors constituting the final price are introduced in Table 4.

IRR (Internal Rate of Return) and NPV (Net Present Value) are two indices used to determine justifiability of an economic project. Considering inflation rate and interest rate in Iran (which is $18 \%$ ), internal rate of return (IRR) of this project is 64.54 , which reflects economic utility of the project for investment.

The NPV index of the studied project is 30,963,537 Euro, which also reflects economic utility of the project. A sensitivity analysis of the IRR index was carried out based on a maximum fluctuation of $20 \%$ in three variables, namely revenue, fixed project expenses, and operational expenses, and results were shown in Figure 2 and Table 5.

As seen in the diagram, the slope of the revenue line is steeper than the other two, and thus revenue variations influence IRR more, which are followed by operational production expenses and investment costs (Figure 3).

The payback period economic index (i.e. the number of years the capital is supplied through the project's yearly monetary revenue) for this project was calculated to be 2.63 years, which seems suitable based on the investment load and production scale.

In fact, all of the production lines will be affected by various conditions that will change the plant's production, sales, and revenue levels. The break-even point index is

Table 4. 120,000 ton/annum specific pellet production costs (Euro/ton).

\begin{tabular}{cc} 
Raw material & 97.96 \\
Salaries \& wages & 0.68 \\
Energy & 7.32 \\
Overhead and Depreciation Costs & 9.35 \\
Other & 3.56 \\
Total & 118.89 \\
\hline
\end{tabular}


Table 5. A sensitivity analysis of the IRR index base on a maximum fluctuation of $20 \%$ in three variables.

\begin{tabular}{cccc}
\hline Operational costs & Capex $^{\mathrm{a}}$ & Income & Change \% \\
\hline 87.86 & 79.84 & 27.64 & -20 \\
83.17 & 76.22 & 34.99 & -16 \\
78.5 & 72.91 & 42.33 & -12 \\
73.83 & 69.89 & 49.7 & -8 \\
69.18 & 67.11 & 57.1 & -4 \\
64.54 & 64.54 & 64.54 & 0 \\
59.92 & 62.17 & 72.02 & 4 \\
55.3 & 59.97 & 79.53 & 8 \\
50.71 & 57.93 & 87.06 & 12 \\
46.12 & 56.01 & 94.62 & 16 \\
41.55 & 54.23 & 102.2 & 20 \\
\hline
\end{tabular}

${ }^{\mathrm{a} C}$ Capital expenditure.

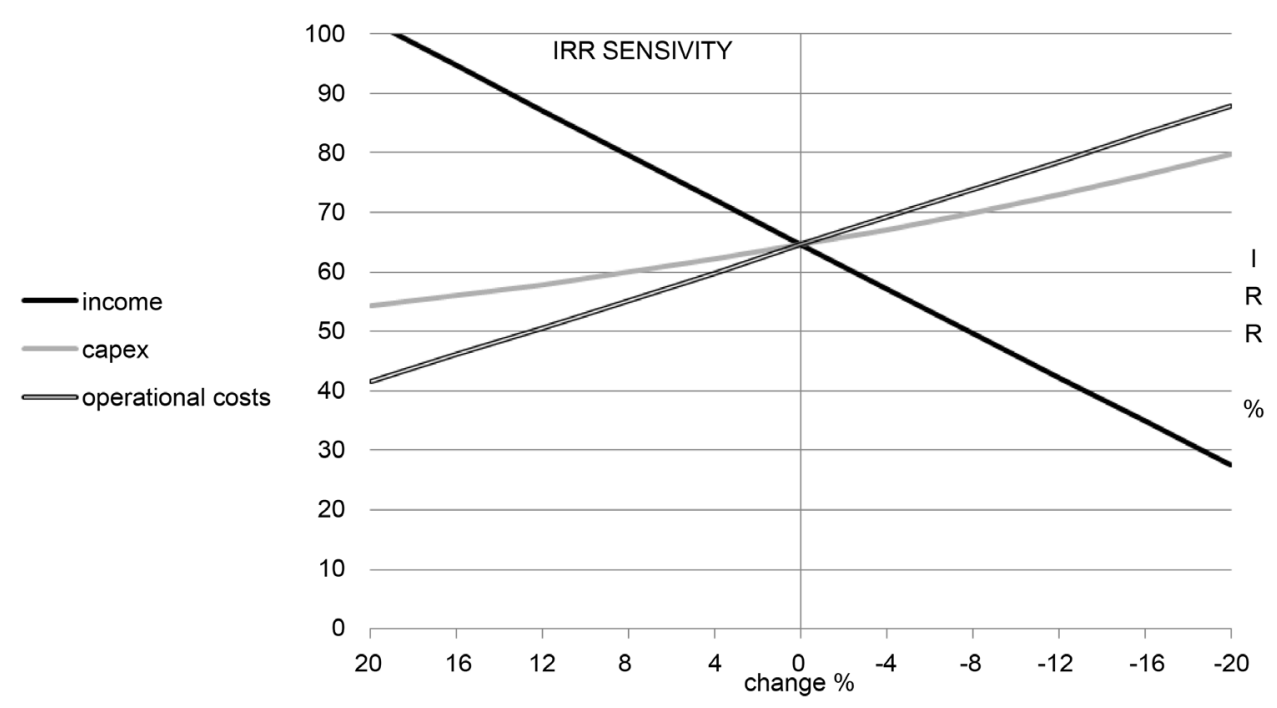

Figure 3. Sensitivity of IRR of the pellet plant with charge of income, CAPEX, operation costs.

defined for such conditions, which is estimated based on satisfaction of revenue production requirements.

COMFAR outputs suggest that expenses will equal the revenue when running at $10 \%$ of the plant's capacity.

\section{Conclusions}

Economic analyses reveal that large-scale production of wood pellet is feasible in Iran. Similar to other parts of the world, the largest portion of the product final price is incurred by supply of raw materials. Iran owns cheap resources of natural gas, which can increase the added value and decrease the final price of the product through optimum 
utilization. It will also bring about a competitive advantage to Iranian producers. The final price of the wood pellet product is 118.89 EUR, which brings about a suitable profit margin to Iranian producers and enables them to compete in global markets.

As mentioned in the "expenses" section, the process of drying raw materials imposes considerable expenses. Moreover, since a moisture content of $50 \%$ is assumed for raw materials based on the project technical information, the maximum consumption of energy by the dryer unit is estimated. However, under actual conditions, a large volume of raw materials will be produced in the form of sawdust and dry wastes by wood workshops and industries, which will significantly contribute to energy saving in this section and will reflect in a reduced final price.

Production of wood pellet in developing countries such as Iran not only leads to realization of environmental goals (such as reducing greenhouse gas emissions), but also does result in productive employment and growth of efficiency of utilization of wood material.

Wood-based panel production industries are also operating in Iran, which are considered competitors in using wood raw materials. However, based on the author's observations and knowledge, there is a large volume of unused wood material in the country, which could be cost effective to collect and process.

\section{References}

[1] Duca, D., Riva, G., Pedretti, E.F. and Toscano, G. (2014) Wood Pellet Quality with Respect to EN 14961-2 Standard and Certifications. Fuel, 135, 9-14. http://dx.doi.org/10.1016/j.fuel.2014.06.042

[2] Kaliyan, N. and Morey, R.V. (2009) Factors Affecting Strength and Durability of Densified Biomass Products. Biomass and bioenergy, 33, 337-359. http://dx.doi.org/10.1016/j.biombioe.2008.08.005

[3] Gilbert, P., Ryu, C., Sharifi, V. and Swithenbank, J. (2009) Effect of Process Parameters on Pelletisation of Herbaceous Crops. Fuel, 88, 1491-1497. http://dx.doi.org/10.1016/j.fuel.2009.03.015

[4] Shahinzadeh, H., ghotb, H., Tavanarad, M., Feghhi, S.A. and Hajahmadi, M. (2012) Estimating the Potential to Achieve Electrical Energy from Biomass Resource in Iran (A Case Study in Isfahan). Journal of Science and Technology, 7, 322-328.

[5] Anon (2008) Agricultural Ministry of Iran, Statistical Book of 2008, Vol. 1, Part 1. http://maj.ir/portal/Home/Default.aspx?CategoryID=20ad5e49-c727-4bc9-9254-de648a5f4d $\underline{52}$

[6] Hamzeh, Y., Ashori, A., Mirzaei, B., Abdulkhani, A. and Molaei, M. (2011) Current and Potential Capabilities of Biomass For green Energy in Iran. Renewable and Sustainable Energy Reviews, 15, 4934-4938. http://dx.doi.org/10.1016/j.rser.2011.07.060

[7] Thek, G. and Obernberger, I. (2012) The Pellet Handbook: The Production And thermal Utilization of Biomass Pellets. Earthscan, London and Washington DC.

[8] Pirraglia, A., Gonzalez, R. and Saloni, D. (2010) Techno-Economical Analysis of Wood Pellets Production for US Manufacturers. BioResources, 5, 2374-2390.

[9] Thek, G. and Obernberger, I. (2004) Wood Pellet Production Costs under Austrian and in Comparison to Swedish Framework Conditions. Biomass and Bioenergy, 27, 671-693. http://dx.doi.org/10.1016/j.biombioe.2003.07.007 
[10] Trømborg, E., Ranta, T., Schweinle, J., Solberg, B., Skjevrak, G. and Tiffany, D.G. (2013) Economic Sustainability for Wood Pellets Production-A Comparative Study between Finland, Germany, Norway, Sweden and the US. Biomass and bioenergy, 57, 68-77. http://dx.doi.org/10.1016/j.biombioe.2013.01.030

[11] Alakangas, E., Junginger, M., Van Dam, J., Hinge, J., Keränen, J., Olsson, O., Vesterinen, P., et al. (2012) EUBIONET III-Solutions to Biomass Trade and Market Barriers. Renewable and Sustainable Energy Reviews, 16, 4277-4290. http://dx.doi.org/10.1016/j.rser.2012.03.051

[12] Karkania, V., Fanara, E. and Zabaniotou, A. (2012) Review of Sustainable Biomass Pellets Production-A Study for Agricultural Residues Pellets' Market in Greece. Renewable and Sustainable Energy Reviews, 16, 1426-1436. http://dx.doi.org/10.1016/j.rser.2011.11.028

[13] Nunes, L.J.R., Matias, J.C.O. and Catalão, J.P. (2014) Economic and Sustainability Comparative Study of Wood Pellets Production in Portugal, Germany and Sweden. In Proceedings of the International Conference on Renewable Energies and Power Quality, Cordoba, 8-10 April 2014, Vol. 14, 526-531. http://www.icrepq.Com/icrepq

[14] Eriksson, L. and Gustavsson, L. (2010) Comparative Analysis of Wood Chips and Bundles-Costs, carbon Dioxide Emissions, Dry-Matter Losses and Allergic Reactions. Biomass and Bioenergy, 34, 82-90. http://dx.doi.org/10.1016/j.biombioe.2009.10.002

\section{Submit or recommend next manuscript to SCIRP and we will provide best service} for you:

Accepting pre-submission inquiries through Email, Facebook, LinkedIn, Twitter, etc. A wide selection of journals (inclusive of 9 subjects, more than 200 journals)

Providing 24-hour high-quality service

User-friendly online submission system

Fair and swift peer-review system

Efficient typesetting and proofreading procedure

Display of the result of downloads and visits, as well as the number of cited articles Maximum dissemination of your research work

Submit your manuscript at: http://papersubmission.scirp.org/ 